\title{
ACTIVITY BASED COSTING DAN SUPPLY CHAIN MANAGEMENT TERHADAP KEUNGGULAN BERSAING
}

\author{
Rima Sundari \\ rimasundari@poltekpos.ac.id \\ Yanisa Zahra N. F. \\ Politeknik Pos Indonesia \\ Jl. Sariasih No.54, Sarijadi, Sukasari, Kota Bandung, Jawa Barat 40151 \\ received: 5/8/2020; revised: 8/9/2020; approved: 28/10/2020
}

\begin{abstract}
Indonesia 's agribusiness industry is lagging behind other countries. The factors that influence this are the inaccessibility of the price of agribusiness products and the inefficient logistics activities that occur in the supply chain. Based on these problems, researchers are interested in examining how activity-based costs and supply chain management influence the competitive advantage of PT Perkebunan Nusantara VIII. This study uses the formulation of an associative problem in the form of a causal relationship with the use of a questionnaire. The population and research sample are employees who are in the management line. The analysis technique used are correlation, multiple regression, and determination coefficient analysis. The results showed a significant influence between activity-based costs and supply chain management on competitive advantage at PT. Perkebunan Nusantara VIII either simultaneously or partially.
\end{abstract}

Keywords: activity based costing; supply chain; competitive advantage; multiple regression; PTPN VIII

\begin{abstract}
Abstrak
Industri agrobisnis Indonesia tertinggal dari negara lain. Faktor yang mempengaruhi hal tersebut adalah tidak terjangkaunya harga produk agrobisnis dan tidak efesiennya aktivitas logistik yang terjadi pada rantai pasok. Berdasarkan permasalahan tersebut peneliti tertarik untuk meneliti bagaimana pengaruh biaya berdasarkan aktivitas dan manajemen rantai pasok terhadap keunggulan bersaing pada PT Perkebunan Nusantara VIII. Penelitian ini menggunakan perumusan masalah asosiatif bentuk hubungan kausal dengan penggunaan kuesioner. Populasi dan sampel penelitian adalah pegawai yang berada pada lini manajemen. Teknik analisis yang digunakan ialah analisis korelasi, regresi berganda, dan koefisien determinasi. Hasil penelitian menunjukkan adanya pengaruh signifikan antara biaya berdasarkan aktivitas dan manajemen rantai pasok terhadap keunggulan bersaing pada PT. Perkebunan Nusantara VIII baik secara simultan maupun parsial.
\end{abstract}

Kata Kunci: biaya berdasarkan aktivitas; rantai pasok; keunggulan bersaing; regresi berganda; PTPN VIII 


\section{PENDAHULUAN}

Indonesia merupakan negara agraris dimana mayoritas penduduknya adalah kaum tani (petani). Sebagai negara agraris, Indonesia memiliki tanah yang luas nan subur. Perkembangan agrobisnis di Indonesia selama ini telah mengalami jatuh bangun. Tidak dapat dipungkiri bahwa sektor ini sangat berpengaruh dalam perkembangan ekonomi di Indonesia baik secara mikro maupun makro. Perbaikan dan pengembangan perlu dilakukan oleh para pelaku usaha agrobisnis ini untuk dapat menyokong perekonomian Indonesia. Namun disisi lain fenomena yang terjadi di Indonesia mengenai sektor agrobisnis ialah industri agrobisnis Indonesia tertinggal dari negara lain.

Seperti yang dilansir dalam laman (Kontan, 2018), industri hilir masih perlu banyak pengembangan agar ekspor Indonesia tidak lagi berbasis produk mentah atau setengah jadi. Namun saat ini, Kementerian Pertanian (Kemtan) masih berfokus pada perwujudan swasambada pangan. Kepala Balai Besar Penelitian dan Pengembangan Paska Panen Kementerian Pertanian mengemukakan bahwa tidak ada investasi asing dalam industri hulu pertanian, meski begitu investasi dalam industri hilir dinilai memungkinkan.

Sektor agrobisnis ini memberikan kontribusi cukup besar bagi pertumbuhan ekonomi. Seperti yang dilansir dalam laman (Detik, 2016), menurut Dewan Komisioner Otoritas Jasa Keuangan (OJK) bahwa kontribusi sektor pertanian mencapai 13,6\% terhadap produk domestik bruto (PDB). Selain itu, sekitar separuh dari sektor pengolahan berbasis pertanian menyerap 35\% tenaga kerja. Apabila sektor pertanian dipandang dari hulu hingga hilir dalam satu rantai, maka kontribusi agregat lebih dari 55\%.

Hal tersebut sejalan dengan fenomena yang terjadi di tahun 2017, seperti yang dilansir dalam laman (Kompas, 2017), meski memiliki peran yang sangat vital, namun pangsa sektor pertanian terhadap perekonomian nasional terus mengalami penurunan. Menurut Asisten Gubernur Kepala Departemen Kebijakan Ekonomi dan Moneter $\mathrm{BI}$, permasalahan tersebut antara lain adalah produksi, distribusi, dan keterjangkauan harga. Tabel 1 merupakan ringkasan fenomena sektor agrobisnis yang terjadi di Indonesia selama 5 tahun terakhir.

Penggunaan perhitungan biaya berdasarkan aktivitas akan memberikan perhitungan yang jauh lebih akurat. Harga dari sebuah produk tentu akan mempengaruhi bagaimana penjualan produk tersebut. Pelanggan cenderung membeli produk yang berkualitas dengan harga yang terjangkau. Seperti yang sudah dikemukakan fenomena yang terjadi adalah bahwa keunggulan bersaing ini tidak dicapai akibat harga hasil sektor Agrobisnis yang terlalu tinggi. Dikutip dari (Kompas, 2017) Bank Indonesia (BI) menyatakan, setidaknya ada tiga permasalahan utama yang dialami sektor pertanian nasional saat ini. Menurut Asisten
Gubernur Kepala Departemen Kebijakan Ekonomi dan Moneter BI, permasalahan tersebut antara lain adalah produksi, distribusi, dan keterjangkauan harga.

Aktivitas produksi ini tentu berkaitan dengan perhitungan harga pokok dari sebuah produk. Keakuratan dalam perhitungan biaya produksi amatlah penting dalam siklus bisnis. Harga sebuah produk harus dapat mencakup seluruh aktivitas dalam proses produksi itu sendiri. Perhitungan biaya berdasarkan aktivitas (ABC) menghitung biaya-biaya berdasarkan aktivitas yang dikonsumsi oleh sebuah produk, metode ini menunjukkan tingkat keakuratan yang lebih baik dibandingkan dengan perhitungan biaya konvensional.

Selain itu permasalahan yang diungkapkan oleh Bank Indonesia dalam kompas.com adalah terkait permasalahan distribusi. Permasalahan dalam distribusi ini antara lain panjangnya tata niaga dan adanya pelaku-pelaku yang dominan di pasar. Di samping itu, pembentukan harga juga dikuasai oleh beberapa pelaku pasar saja. Dikutip dari (supplychainindonesia, 2014) diungkapkan bahwa permasalahan lain yang dihadapi sektor agrobisnis dalam hal rantai pasok (SCM) antara lain: (a) Masih kurangnya koordinasi dalam hal pengambilan produk antara produsen dan pelaku pasar; (b) Jarak yang jauh dan rute dari tempat hasil pertanian (umumnya daerah) menuju ke kota; (c) Kendala dalam hal handling, staging, dan storage; (d) Masalah proses pendinginan pada saat pascapanen; (e) Masalah packaging, tracking dan inventory control.

Penggunaan manajemen rantai pasok merupakan langkah yang perlu diambil untuk mengatasi permasalahan rantai pasok tersebut. Menurut Indrajit dalam (Kurniawan, 2016) supply chain management merupakan suatu sistem tempat organisasi menyalurkan barang produksi dan jasanya kepada pelanggan. Rantai ini merupakan jaringan atau jejaring dari berbagai organisasi yang saling berhubungan yang mempunyai tujuan yang sama yaitu sebaik mungkin menyelenggarakan pengadaan atau penyaluran barang dan jasa tersebut. Metode ini memperhitungkan biaya logistik mulai dari pengadaan hingga distribusi barang kepada pelanggan serta pengaturan atau manajemen terhadap suatu barang atau produk hingga pada tangan konsumen.

Sektor agrobisnis ini cukup luas dan memiliki banyak subsektor seperti hortikultura, kehutahan, perikanan, perkebunan, peternakan, dan tanaman pangan. Objek yang akan diteliti adalah subsektor perkebunan. Banyaknya penutupan usaha pada subsektor perkebunan menyebabkan sektor agrobisnis ini mengalami kemunduran dibandingkan dengan negara lain. Seperti fenomena yang telah dipaparkan diatas bahwa cukup banyak permasalahan yang dapat menghambat sektor ini.

Tabel 2 menunjukkan perusahaan yang bergerak di subsektor perkebunan mengalami penambahan dan pengurangan setiap tahunnya. Untuk perusahaan perkebunan jenis tanaman karet, kelapa sawit, kopi, 
teh, tebu dan tembakau mengalami kenaikan dan penurunan yang fluktuatif, sedangkan untuk perusahaan perkebunan jenis tanaman kelapa dan kakao mengalami penurunan dan untuk perusahaan perkebunan jenis tanaman cengkeh, kapuk dan kina mengalami stagnan setiap tahunan. Prosentase interprestasi berdasarkan Tabel 2 bahwa sebanyak $54,5 \%$ perusahaan perkebunan mengalami fluktuasi penambahan dan penutupan $18,2 \%$ perusahaan perkebunan mengalami penutupan, dan $27,3 \%$ perusahaan perkebunan mengalami stagnasi. Hal ini dapat menjadi perhatian penting bagi para pelaku usaha sektor agrobisnis untuk menentukan bagaimana strategi yang baik melalui metode dan kebijakan yang digunakan dalam perusahaan untuk dapat bersaing dalam persaingan internasional. Harga dapat menjadi faktor utama dalam hal keunggulan bersaing perusahaan, dimana harga yang bersaing serta kualitas yang terbaik tentu dapat memberikan ketahanan dalam persaingan bisnis nasional maupun internasional.

Berdasarkan seluruh fenomena mengenai sektor agrobisnis yang terjadi selama 5 (lima) tahun terakhir, permasalahan utama yang terjadi adalah tertinggalnya sektor agrobisnis di Indonesia yang disebabkan oleh faktor yang lebih spesifik yaitu keterjangkauan harga, produksi, dan distribusi rantai pasok. Penelitian ini merupakan replikasi dari penelitian yang telah dilakukan sebelumnya oleh Kurniawan (2016). Berdasarkan hasil dari penelitian tersebut diketahui bahwa supply chain management yang diterapkan pada perusahaan yang diteliti termasuk dalam klasifikasi baik, dan keunggulan bersaing pun berada pada klasifikasi yang baik. Sehingga hasil akhir dalam penelitian ini adalah supply chain management berpengaruh positif terhadap keunggulan bersaing.

Objek yang diteliti adalah PT. Perkebunan Nusantara VIII. Perusahaan perkebunan ini merupakan salah satu pelaku usaha sektor agrobisnis dalam subsektor perkebunan dengan usaha yang dikelola adalah teh, karet, kopi, kelapa sawit, agrowisata, dan industri hilir teh.

\section{METODE}

Penelitian ini termasuk penelitian deskriptif bersifat verifikatif dengan perumusan masalah asosiatif bentuk hubungan kausal. Populasi terdiri dari pegawai tetap yang berada pada lini manajemen PT. Perkebunan Nusantara VIII. Pengambilan sampel dilakukan dengan teknik nonprobability sampling dengan purposive sampling. Kriteria yang ditentukan adalah sebagai berikut: (1) Ketua sub divisi dan ketua divisi yang memiliki keterlibatan dalam perhitungan dan implementasi activity based costing dan supply chain management; (2) Ketua sub divisi dan ketua divisi yang memiliki keterlibatan dengan perancangan strategi baru dalam evaluasi implementasi activity based costing dan supply chain management; (3) Ketua sub divisi dan ketua divisi yang setidaknya pernah terlibat dalam perhitungan, implementasi, dan perancangan strategi baru dalam evaluasi implementasi activity based costing dan supply chain management (Tabel 3).

Operasionalisasi variabel ditunjukkan pada Tabel 4. Teknik pengumpulan data menggunakan kuisioner. Suatu kuesioner dinyatakan valid jika pertanyaan pada kuesioner mampu mengungkapkan sesuatu yang diukur oleh kuesioner tersebut. Reliabilitas diukur menggunakan koefisien Cronbach Alpha (a) > 0,60 . Uji normalitas dilihat melalui penyebaran data berdasarkan probability plot. Analisis regresi ganda digunakan dengan dua variabel independen. Koefisien determinasi menunjukkan suatu proporsi dari varian yang dapat diterangkan oleh persamaan regresi terhadap varian total.

\section{HASIL}

Penelitian yang telah dilakukan merupakan penelitian dengan menggunakan data primer. Alat yang digunakan sebagai instrumen penelitian ini adalah kuesioner. Dimana penelitian ini bersifat deskriptif verifikatif dengan hubungan kausal. Objek yang menjadi tempat penelitian merupakan salah satu pelaku usaha sektor agrobisnis yaitu PT. Perkebunan Nusantara VIII. Dalam penelitian ini penulis menggunakan 6 (enam) tahapan yaitu tahap mendeskripsikan data responden, tahap akumulasi jawaban responden, tahap pengujian alat ukur, tahap uji normalitas, tahap analisis korelasi, tahap analisis regresi liner berganda, tahap analisis koefisien determinasi dan tahap pengujian hipotesis.

Berdasarkan perhitungan jawaban responden terhadap indikator-indikator dari variabel $\mathrm{ABC}$, secara keseluruhan 73,6\% (dengan nilai 501) responden menjawab sangat setuju, 25\% (nilai 174) responden menjawab setuju, $0,7 \%$ (nilai 5 ) responden menjawab ragu-ragu, $0 \%$ responden menjawab tidak setuju dan $0 \%$ responden menjawab sangat tidak setuju. Maka dapat disimpulkan bahwa mayoritas responden menjawab sangat setuju berdasarkan hasil akumulasi. Secara kumulatif responden memberikan skor total 3216.

Berdasarkan perhitungan jawaban responden terhadap indikator-indikator dari variabel SCM, secara keseluruhan 54,3\% (dengan nilai 220) responden menjawab sangat setuju, 44,5\% (nilai 180) responden menjawab setuju, $1,2 \%$ (nilai 5) responden menjawab ragu-ragu, $0 \%$ responden menjawab tidak setuju dan $0 \%$ responden menjawab sangat tidak setuju. Maka dapat disimpulkan bahwa mayoritas responden menjawab sangat setuju berdasarkan hasil akumulasi. Secara kumulatif responden memberikan skor total 1815 .

Berdasarkan perhitungan jawaban responden terhadap indikator-indikator dari variabel Keunggulan Bersaing, secara keseluruhan 46,8\% (dengan nilai 187) responden menjawab sangat setuju, $44,5 \%$ (nilai 194) 
responden menjawab setuju, 4,8\% (nilai 19) responden menjawab ragu-ragu, $0 \%$ responden menjawab tidak setuju dan $0 \%$ responden menjawab sangat tidak setuju. Maka dapat disimpulkan bahwa mayoritas responden menjawab setuju berdasarkan hasil akumulasi. Secara kumulatif responden memberikan skor total 1768.

Variabel activity based costing terdiri dari 17 item pertanyaan dengan 7 indikator. Hasil uji validitas menunjukkan bahwa semua item telah memenuhi syarat pengujian dimana nilai rhitung $>$ rtabel sebesar 0,312 . Hasil yang sama juga diperoleh supply chain management dari 10 item pertanyaan dengan 5 indikator. Demikian pula, keunggulan bersaing diukur dengan 10 item pertanyaan dengan 5 indikator. Hal tersebut menunjukkan bahwa instrumen penelitian dapat mengukur variabel yang diteliti.

Berdasarkan hasil perhitungan menggunakan program SPSS 15.0 activity based costing memiliki tingkat reliabilitas sebesar 0,903 , supply chain management memiliki tingkat reliabilitas sebesar 0,838, dan variabel keunggulan bersaing memiliki tingkat reliabilitas sebesar 0,665 . Sehingga dapat dikatakan bahwa hasil jawaban layak dan konsisten dalam mengukur apa yang hendak diukur untuk ketiga variabel tersebut.

Pengujian normalitas dengan melihat probability plot terlihat bahwa titik-titik menyebar di sekitar garis diagonal dan mengikuti arah garis diagonal. Hal ini menunjukkan bahwa model regresi telah memenuhi uji asumsi normalitas.

Berdasarkan Tabel 5 diketahui bahwa Sig. F. Change sebesar 0,000, menunjukkan bahwa terdapat hubungan yang kuat dan searah antara activity based costing, supply chain management dan keunggulan bersaing. Berdasarkan Tabel 6 diketahui bahwa nilai persamaan regresi berganda antara activity based costing dan supply chain management terhadap keunggulan bersaing adalah sebagai berikut:

$$
\mathrm{Y}=-16,051+0,379 \mathrm{X}_{1}+0,297 \mathrm{X}_{2}
$$

Konstanta negatif menunjukkan terjadinya penurunan keunggulan bersaing sebesar -16,051, kondisi ini timbul karena keunggulan bersaing sangat resisten terhadap persaingan antara perusahaan, jika perusahaan tidak dapat mempertahankan keunggulan bersaingnya maka tidak menutup kemungkinan perusahaan akan mengalami likuidasi karena tidak dapat memenuhi permintaan atau kebutuhan pasar.

Hasil perhitungan koefisien determinasi (Tabel 5) memiliki arti bahwa keunggulan bersaing pada PT. Perkebunan Nusantara VIII dipengaruhi oleh activity based costing dan supply chain management sebesar $54,3 \%$. Berdasarkan Tabel 5 dapat dilihat bahwa activity based costing dan supply chain management berpengaruh signfikan terhadap keunggulan bersaing baik secara simultan maupun parsial.

\section{PEMBAHASAN}

Penelitian lebih lebih mengacu pada implementasi dan dampak implementasi activity based costing dalam perusahaan. Berdasarkan 7 (tujuh) indikator yang digunakan PT. Perkebunan Nusantara VIII telah melakukan implementasi activity based costing dengan sangat baik dengan jumlah skor sebesar 3216 dari 3400. Angka tersebut berada pada kategori sangat tinggi, perusahaan pun telah melakukan manajemen rantai pasok dengan baik yang ditunjukkan dengan angka sebesar 1815 dari 2000. Tercapainya keunggulan bersaing pada persaingan pasar secara global merupakan bentuk implementasi dari penggunaan metode-metode yang tepat.

Dominannya kontribusi dari penggunaan metode perhitungan biaya berdasarkan aktivitas ini sesuai dengan analisis deskriptif yang menjelaskan bahwa implementasi activity based costing pada PT. Perkebunan Nusanta telah berada pada kelompok yang cukup baik. Indikator yang membentuk dominannya activity based costing pada PT. Perkebunan Nusantara VIII adalah harus dengan adanya dukungan manajemen puncak (top management support), meningkatkan kompetisi di pasar (competition), harus diadakan evaluasi secara konsisten terhadap implikasi dari penggunaan metode perhitungan biaya berdasarkan aktivitas serta pemberian kompensasi atas kinerja pegawai yang memberikan informasi biaya melalui activity based costing (performance evaluation \& compensation), perlu diakannya pelatihan-pelatihan khusus bagi pegawai yang melakukan rotasi dan terlibat pada perhitungan biaya berdasarkan aktivitas (training), adanya keterlibatan antara setiap divisi dalam setiap transaksi serta adanya otorisasi dari setiap divisi yang terlibat dalam perhitungan biaya berdasarkan aktivitas (non-accounting ownership). Selain itu perusahaan selalu melakukan seleksi ketat dalam penerimaan pegawai baru dan menempatkan pada posisi sesuai dengan keahliannya (resources) dan yang terakhir adalah harus diadakannya rapat untuk mengambil keputusan atas informasi yang dihasilkan dari perhitungan biaya berdasarkan aktivitas untuk memutuskan tingkat keakurasian dan ketersediaan data serta untuk memutuskan apa yang hendak dicapai atas penerapan metode activity based costing.

Memahami hasil pengujian statistik dapat dijelaskan bahwa naik atau turunnya keunggulan bersaing perusahaan salah satunya ditentukan oleh penggunaan metode perhitungan biaya berdasarkan aktivitas (activity based costing). Kontribusi dari implementasi manajemen rantai pasok ini sesuai dengan analisis deskriptif yang menjelaskan bahwa manajemen rantai pasok (supply chain management) pada PT. Perkebunan Nusantara VIII telah berada pada kelompok yang baik.

Indikator yang membentuk dominannya supply chain management pada PT. Perkebunan Nusantara VIII adalah perusahaan harus memiliki kemampuan 
melaksanakaan pekerjaan secara tepat waktu dan memenuhi perfect order fulfillment secara konsisten (reliability), mampu memenuhi keingin pelanggan sesuai dengan waktu yang telah ditentukan dan memiliki kemapuan dalam merespon perubahan eksternal agar tetap kompetitif dipasar (responsiveness), memiliki fleksibilitas dan adaptabilitas untuk dapat mengelola resiko rantai pasok secara lebih baik (agility), manajemen rantai pasok dapat meminimalisir biaya sehingga tercipta efesiensi biaya sehingga dapat menurunkan harga pokok produk (costs) dan yang terakhir adalah perusahaan memiliki kemampuan untuk memanfaatkan aset secara produktif serta memiliki utilisasi kapasitas yang tinggi (assets management efficiency).

Implementasi manajemen rantai pasok pada perusahaan dapat memberikan nilai lebih bagi perusahaan dimata supplier dan konsumennya, dengan adanya supplier partnering, pasokan yang dibutuhkan oleh perusahaan akan menjadi lebih baik dan lebih struktur, sedangkan pelayanan hingga pada konsumen akan memberikan kepuasan pada konsumen itu sendiri.

Hasil pada penelitian ini sejalan dengan beberapa penelitian-penelitian terdahulu. Seperti pada penelian (Marlina, 2017) dikatakan bahwa activity based costing ini dapat berpengaruh terdahap keunggulan bersaing pada Perguruan tinggi. Adapun penelitian dari (Rendy dan Devie, 2014) diungkapkan bahwa hasil dari penelitian terdapat pengaruh antara Activity Based Costing terhadap keunggulan bersaing pada perusahaan di Surabaya. Variabel lain yang mendukung Keunggulan Bersaing seperti Supply Chain Management pun memiliki pengaruh yang cukup besar, seperti pada penelitian (Kurniawan, 2016) dikemukakan bahwa Supply chain management berpengaruh positif terhadap keunggulan bersaing perusahaan di Tasikmalaya. Pada penelitian yang dilakukan oleh (Fei dan Isa, 2010) dikemukakan bahwa hasil penelitian menunjukkan bahwa upaya peningkatan kualitas informasi sepanjang rantai pasokan tertentu adalah tindakan terpenting yang dapat diambil manajemen. Secara berurutan, hal terpenting berikutnya adalah meningkatkan kepercayaan, pemasok strategis kemitraan dan hubungan pelanggan.

\section{KESIMPULAN}

Keunggulan bersaing yang dimiliki oleh PT. Perkebunan Nusantara VIII berada pada kategori sangat baik. Perusahaan memiliki kemampuan untuk menyajikan setiap operasi bisnisnya secara lebih baik, sehingga harga jual menjadi lebih terjangkau dengan kualitas terbaik. Kesimpulan penelitian ini (1) terdapat pengaruh signifikan activity based costing dan supply chain management terhadap keunggulan bersaing secara simultan pada PT. Perkebunan Nusantara VIII. Penerapan activity based costing dan supply chain management bersama-sama memiliki pengaruh dalam meningkatkan keunggulan bersaing suatu perusahaan; (2) terdapat pengaruh signifikan activity based costing terhadap keunggulan bersaing pada PT. Perkebunan Nusantara VIII. Penerapan metode perhitungan biaya berdasarkan aktivitas memiliki pengaruh untuk meningkatkan keunggulan bersaing suatu perusahaan. (3) Terdapat pengaruh signifikan supply chain management terhadap keunggulan bersaing pada PT. Perkebunan Nusantara VIII. Penerapan manajemen rantai pasok memiliki pengaruh untuk meningkatkan keunggulan bersaing suatu perusahaan.

\section{DAFTAR PUSTAKA}

Aidilha, S. S. 2018. Pengaruh Dimensi Supply Chain Management Terhadap Keunggulan Bersaing Pada UMKM Sentra Industri Keripik Di Jalan Pagar Alam Bandar Lampung. Skripsi tidak diterbitkan. Bandar Lampung: Universitas Lampung

Fei, Z. Y., \& Isa, C. R. 2010. Factors Influencing Activity-Based Costing Success: A Review Summary of Previous Research. Cbetm, 26-28.

Indrajit, R. E. \& Djokopranoto, R. 2016. Supply Chain Management Edisi ke-2. Yogyakarta: Preinexus

Kurniawan, D. 2016. Pengaruh Supply Chain Management Terhadap Keunggulan Bersaing Pada Perusahaan Plaza Asia Tasikmalaya. Tasikmalaya: Universitas Siliwangi.

Kontan. 2018. Industri agribisnis Indonesia tertinggal dari negara lain (Online). (https://industri.kontan. co.id/news/kadin-industri-agribisnis-indonesiatertinggal-dari-negara-lain, diakses tanggal 12 Februari 2019).

Marlina, E. 2017. Analisis Pengaruh Activity Based Costing Terhadap Keunggulan Bersaing Perguruan Tinggi. Riau: Universitas Muhammadiyah Riau.

Perdana, T. 2014. Perkembangan Rantai Pasok Pertanian di Indonesia (Online). (http://supplychainindonesia. com/new/perkembangan-rantai-pasok-pertaniandi-indonesia/, diakses tanggal 27 Januari 2019)

Pujawan, N., \& Mahendrawhati. 2017. Supply Chain Management Edisi ke-3. Yogyakarta: Andi Offset

Radar Semarang. 2017. Sistem Logistik Pangan Masih Belum Optimal (Online). (http://radarsemarang. com/2017/10/16/sistem-logistik-pangan-masihbelum-optimal/, diakses tanggal 13 Februari 2019)

Rendy \& Devie. 2014. Analisa Pengaruh Activity Based Costing Terhadap Keunggulan Bersaing Dan Kinerja Organisasi. Jurnal Bussines Accounting. Surabaya: Universitas Kristen Petra.

Setiawan, S. R. D. 2017. Tiga Masalah Utama Sektor Pertanian Nasional (Online).(https://bisniskeuangan. kompas.com/read/2017/03/30/204932226/tiga. masalah.utama.sektor.pertanian.nasional.apa.saja, diakses tanggal 13 Februari 2019) 
Tabel 1. Fenomena Sektor Agrobisnis

\begin{tabular}{|c|c|c|c|c|}
\hline No & Sumber & Permasalahan & Tgl Publikasi & Faktor Permasala-han \\
\hline 1. & Kontan.co.id & $\begin{array}{l}\text { Industri Agrobis-nis Indonesia } \\
\text { tertinggal dari negara lain }\end{array}$ & $15 / 02 / 18$ & $\begin{array}{l}\text { - Stabilitas harga } \\
\text { - Tidak efesiennya aktivitas logistik yang }\end{array}$ \\
\hline 2. & Kompas.com & $\begin{array}{l}\text { Pangsa sektor agrobisnis terhadap } \\
\text { perekonomi-an nasional terus mengala- } \\
\text { mi penurunan }\end{array}$ & $30 / 03 / 17$ & $\begin{aligned} & \text { terjadi pada rantai pasok } \\
\text { - } & \text { Harga hasil sektor Agrobisnis yang tinggi } \\
\text { - } & \text { Permasalahan dalam bidang distribusi }\end{aligned}$ \\
\hline 3. & Radarsemarang.com & $\begin{array}{l}\text { Sistem logistik pangan masih belum } \\
\text { optimal }\end{array}$ & $16 / 10 / 17$ & $\begin{array}{l}\text { - Masih kurangnya koordinasi } \\
\text { - Kendala dalam hal handling, staging, dan }\end{array}$ \\
\hline 4. & Supplychainindonesia.com & $\begin{array}{l}\text { Harga hasil sektor agrobisnis yang } \\
\text { tinggi }\end{array}$ & $12 / 02 / 14$ & $\begin{array}{l}\text { storage. } \\
\text { - Masalah packaging, tracking dan } \\
\text { inventory control. }\end{array}$ \\
\hline
\end{tabular}

Sumber: Diolah Penulis (2019)

Tabel 2. Jumlah Perusahaan Perkebunan Besar Menurut Jenis Tanaman Tahun $2012-2016$

\begin{tabular}{lrrrrr}
\hline Jenis Tanaman & 2012 & 2013 & 2014 & 2015 & 2016 \\
\hline \multicolumn{5}{c}{ Tanaman Tahunan } \\
\hline Karet & 332 & 315 & 315 & 316 & 315 \\
Kelapa & 111 & 107 & 107 & 107 & 107 \\
Kelapa sawit & 1510 & 1601 & 1601 & 1600 & 1592 \\
Kopi & 97 & 89 & 89 & 91 & 89 \\
Kakao & 87 & 86 & 86 & 85 & 80 \\
Teh & 114 & 96 & 96 & 98 & 97 \\
Cengkeh & 55 & 52 & 52 & 52 & 52 \\
Kapuk & 1 & 1 & 1 & 1 & 1 \\
Kina & 2 & 2 & 2 & 2 & 2 \\
\hline \multicolumn{7}{c}{ Tanaman semusim } & & \\
\hline Tebu & 99 & 97 & 97 & 98 & 98 \\
Tembakau & 7 & 6 & 6 & 8 & 7 \\
\hline Sumber: Badan Pusat Statistik (2019)
\end{tabular}

Sumber: Badan Pusat Statistik (2019)

Tabel 3. Sampel Terpilih

\begin{tabular}{ll}
\hline \multicolumn{1}{c}{ Divisi } & \multicolumn{1}{c}{ Jabatan } \\
\hline S e k reta r is & Kasubdiv GCG \& Manajemen Resiko \\
Perusahaan & Pymt. Kasubdiv Humas, Kelembagaan \& \\
& PKBL \\
Audit Internal & Kepala Divisi Audit Internal \\
& Kasubdiv Pengawasan I \\
& Kasubdiv Pengawasan II \\
& Pymt. Kasubdiv Pengawasan III \\
Perencanaan \& & Kepala Divisi Perencanaan \& Pengembangan \\
Pengembangan & Bisnis \\
Bisnis & Kasubdiv Manajemen Kinerja \\
& Pymt. Kasubdiv Pengelolaan \& Pendayagunaan \\
& Aset \\
& Kasubdiv Riset \& Pengembangan Bisnis \\
Tanaman & Kepala Divisi Tanaman \\
& Kasubdiv Aneka Tanaman \& Hortikultura \\
\hline
\end{tabular}

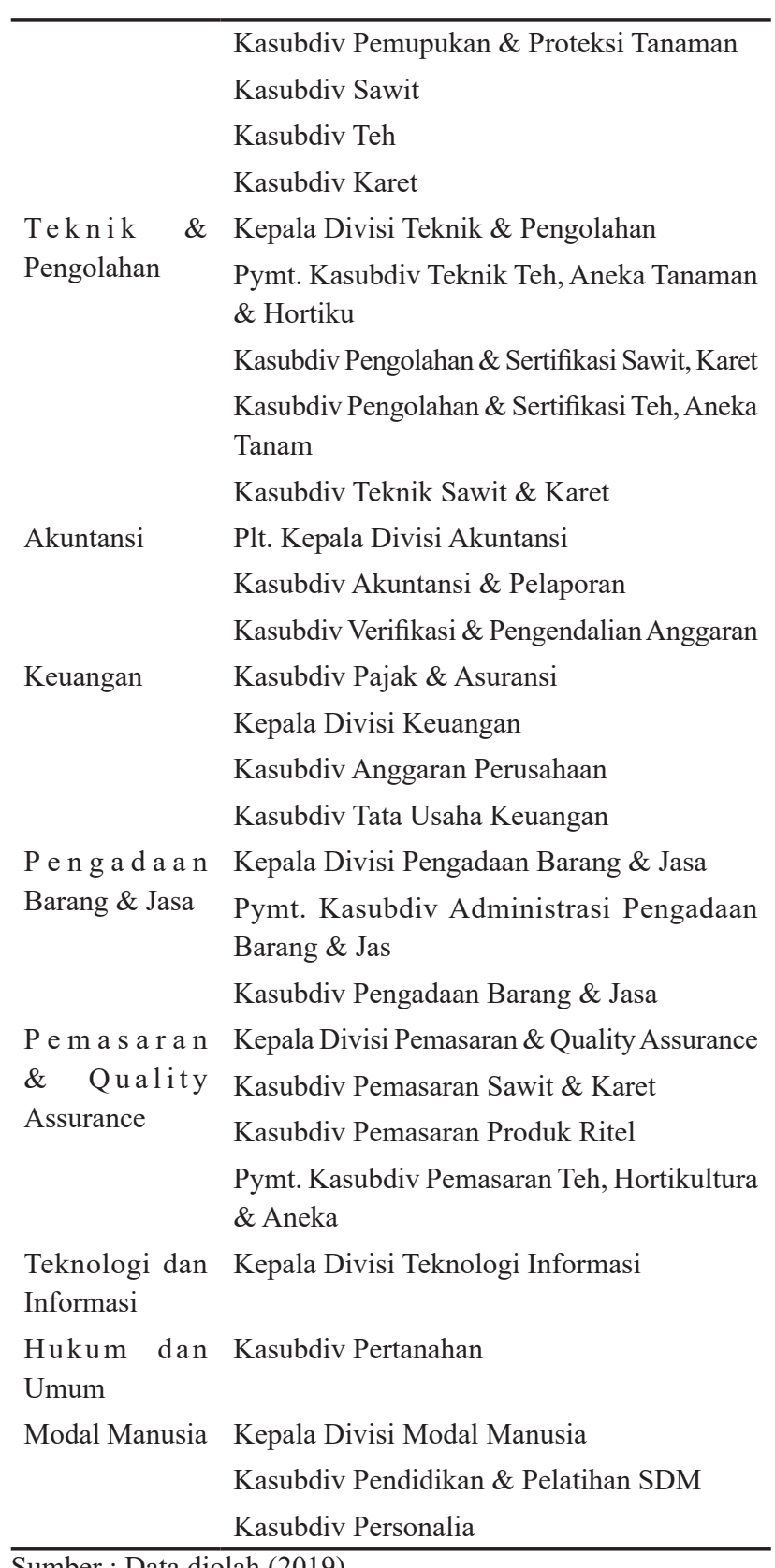


Tabel 4. Operasionalisasi Variabel

\begin{tabular}{|c|c|c|}
\hline Variabel & Indikator & Skala Ukur \\
\hline $\begin{array}{l}\mathrm{X}_{1} \\
\text { Activity } \\
\text { Based } \\
\text { Costing }\end{array}$ & $\begin{array}{l}\text { 1. Top management support } \\
\text { 2. Competition } \\
\text { 3. Performance evaluation and } \\
\text { compensation } \\
\text { 4. Training } \\
\text { 5. Non-accounting ownership } \\
\text { 6. Resources } \\
\text { 7. Consesus and clarity of objective } \\
\text { Sumber: Marlina (2017:67) }\end{array}$ & Interval \\
\hline $\begin{array}{l}\mathrm{X}_{2} \\
\text { Supply } \\
\text { Chain } \\
\text { Management }\end{array}$ & $\begin{array}{l}\text { 1. Reliability } \\
\text { 2. Responsiveness } \\
\text { 3. Agility } \\
\text { 4. Costs } \\
\text { 5. Asset Management Efficiency } \\
\quad \text { (Assets) } \\
\text { Sumber : Pujawan \& } \\
\text { Mahendrawhati (2017:282) }\end{array}$ & Interval \\
\hline $\begin{array}{l}\text { Y } \\
\text { Keunggulan } \\
\text { Bersaing }\end{array}$ & $\begin{array}{l}\text { 1. Harga } \\
\text { 2. Kualitas } \\
\text { 3. Delivery Dependability } \\
\text { 4. Inovasi produk } \\
\text { 5. Time to market } \\
\text { Sumber : Aidilha (2018:23) }\end{array}$ & Interval \\
\hline
\end{tabular}

Sumber : Diolah (2019)
Tabel 5. Hasil Uji Korelasi Berganda

\begin{tabular}{|c|c|c|c|c|c|c|}
\hline Model & $\mathrm{R}$ & $\begin{array}{c}\mathrm{R} \\
\text { Square }\end{array}$ & \multicolumn{2}{|c|}{$\begin{array}{l}\text { Adjusted } \\
\text { R Square }\end{array}$} & \multicolumn{2}{|c|}{$\begin{array}{l}\text { Std. Error of } \\
\text { the Estimate }\end{array}$} \\
\hline 1 &, $737^{\mathrm{a}}$ &, 543 & \multicolumn{2}{|c|}{, 519} & \multicolumn{2}{|c|}{2,559} \\
\hline R Square Change & F Change & df1 & \multicolumn{2}{|c|}{ Df2 } & \multicolumn{2}{|c|}{ Sig. F Change } \\
\hline ,543 & 22,003 & 2 & \multicolumn{2}{|c|}{37} & \multicolumn{2}{|c|}{, 000} \\
\hline \multicolumn{7}{|c|}{ Sumber : Data diolah melalui SPSS 15.0} \\
\hline \multicolumn{7}{|c|}{ Tabel 6. Hasil Uji Regresi Linier Berganda } \\
\hline & $\mathrm{B}$ & d. Error & Beta & B & & Sig. \\
\hline (Constant) & $-16,051$ & 13,293 & & $-1,20$ & & ,235 \\
\hline $\begin{array}{l}\text { Activity Based } \\
\text { Costing }\end{array}$ & ,379 &, 176 & ,254 & 2,15 & & ,038 \\
\hline $\begin{array}{l}\text { Supply Chain } \\
\text { Management }\end{array}$ & 675 &, 130 & ,612 & 5,18 & &, 000 \\
\hline
\end{tabular}

Sumber : Data diolah melalui program SPPS 15.0 